\title{
МОЖЛИВОСТІ АВТОМАТИЗОВАНИХ ІНФОРМАЦЙНО-ПОШУКОВИХ СИСТЕМ І ТЕХНОЛОГІЙ ШТУЧНОГО ІНТЕЛЕКТУ В НЕПРОЦЕСУАЛЬНІЙ ФОРМІ ВИКОРИСТАННЯ СПЕЦАЛЬНИХ ЗНАНЬ ПРИ РОЗСЛІДУВАННІ КОРУПЦІЙНИХ ЗЛОЧИНІВ
}

\begin{abstract}
ДАНЫШИН Максим Валерійович - професор, доктор юридичних наук, професор кафедри права Національної безпеки та правової роботи Військово-юридичного інституту Національного юридичного університету імені Ярослава Мудрого

КОВАЛЬОВ Юрій Юрійович - аспірант Харківський науково-дослідний інститут судових експертиз імені Заслуженого професора М. С. Бокаріуса
\end{abstract}

DOI:10.32782/EP.2020.2.13

\begin{abstract}
У статті визначено місие і роль автоматизованих інформаційно-пошукових систем як непроцесуальної борми використання спеціальних знань при розслідуванні корупиійних злочинів. Відзначається, що на практиці їх використання пов'язується насамперед 3 необхідністю отримання орієнтуючої інформачї у провадженнях зазначеной категорій, що значно розширюе практичні можливості слідчого в пізнанні явищ $i$ процесів, які $\varepsilon$ характерними саме для корупиійноӥ злочинной діяльності з урахуванням специбіки останньої. Звертається увага на процесуальні недоліки щооо відсутності правових підстав використання иієї облікової інбормацї у якості самостійних джерел доказів, що значною мірою знижує кількість звернень до криміналістичної облікової інбормачї, тим самим, перешкоджаючи своєчасному розслідуванню $i$ розкриттю злочинів, веде до утворення иілого ряду проблем, е тому иислі $i$ до відсутності порівняльного матеріалу, використовуваного для поповнення баз даних. Обгрунтовано необхідність внесення доповнень до КПК України щодо усунення цих помилок. Розглядається сучасний стан технологій штучного інтелекту, його поняття та основні напрямки розвитку. Відзначається, щзо забезпечення кримінального судочинства новітніми системами итучного інтелекте має безліч переваг, які виявляються насамперед е можливості обробки та аналізу величезних масивів даних у максимально стислі строки, що набуває суттєвого значення в умовах надмірноӥ завантаженості слідчих, які з об'єктивних причин не в змозі
\end{abstract}

приділити достатнъої уваги здійсненню грунтовной аналітичної роботи, на виконання якої може знадобитися більше часу, ніж иее було б можливо у межах розслідування кримінального провадження. 3 огляду на зазначене запропоновано створення $i$ впровадження у правоохоронну діяльність автоматизованої консультаційно-аналітичної системи під умовною назвою «Протидія корупиійній злочинності», що може слугувати додатковим методичним ресурсом, який забезпечить інбормачійний криміналістичний супровід розслідування корупційних злочинів та дозволить компенсувати відсутність практичного досвіду у співробітників правоохоронних органів, які здійснюють кримінальне провадження щзодо иієё категорї̈ злочинів.

Ключові слова: злочин, корупчія, протидія, криміналістика, експертно-криміналістичні обліки, технологї штучного інтелекту.

\section{Постановка проблеми}

Під час розслідування корупційних злочинів суттєву роль відіграють непроцесуальні форми використання спеціальних знань. Їх використання пов'язується насамперед 3 необхідністю отримання орієнтуючої інформації у провадженнях зазначеної категорії, що значно розширює практичні можливості слідчого в пізнанні явищ і процесів, які є характерними саме для корупційної злочинної діяльності з урахуванням специфіки останньої. За їх допомогою слідчий має змогу з'ясувати додаткові факти та відомості про обставини, при яких були до- 


\section{Кримінальне право, кримінальний процес та криміналістика}

пущені розтрати, нестачі або інші службові зловживання, одержати спеціальні довідкові дані стосовно особливостей фінансовогосподарської діяльності юридичної особи, порядку ведення бухгалтерського обліку і фінансової звітності в даному господарюючому суб'єкті, практики укладення й виконання окремих видів господарських договорів та, відповідно, перевірити правильність та законність дій уповноважених службових осіб. Особливе місце у цьому аспекті займає проблема дослідження місця і ролі автоматизованих інформаційно-пошукових систем і технологій штучного інтелекту як непроцесуальної форми використання спеціальних знань при розслідуванні зазначених злочинів.

\section{Ступінь розробленості проблеми}

Дослідженню теоретичних і практичних аспектів використання спеціальних знань під час розслідування злочинів у різний час приділяло увагу багато вітчизняних та зарубіжних науковців, зокрема: Т.В. Авер' янова, Л.Ю. Ароцкер, Р.С.Бєлкін, А.I. Вінберг, Г.І. Грамович, Г.Г. Зуйков, П.П. Іщенко, Н.І. Клименко, Ю.Г. Корухов, В.К. Аисиченко, Н.П. Майліс, В.М. Махов, О.Р. Росинська, М.Я. Сегай, В.В. Семенов, I.M. Сорокотягін, В.В. Ціркаль, А.Г. Шапіро, В.Ю. Шепітько, В.І. Шиканов, М.Г. Щербаковський та інші вчені. Але, нажаль, проблемні питання непроцесуальних форм використання спеціальних знань при розслідуванні корупційних злочинів висвітлювалися лише фрагментарно, зокрема у наукових працях 3.T. Баранової, Ю.В. Бауліна, Н.В. Кимлик, В.В. Крюкова, М.М. Лашка, М.В. Аяміна, Я.Е. Мишкова, В.О. Навроцького, О.В. Пчеліної та інших науковців.

\section{Постановка завдання}

Метою цієї статті є дослідження місця i ролі автоматизованих інформаційно-пошукових систем як непроцесуальної форми використання спеціальних знань при розслідуванні корупційних злочинів. Ми пропонуємо більш детально дослідити можливості новітніх технологій штучного інтелекту в діяльності щодо протидії корупційній злочинності при реалізації правоохоронної функції.

\section{Виклад основного матеріалу}

Як відзначається в криміналістичній літературі, інтегрована інформаційно-пошукова система (далі - IIПС) є сукупністю організаційно-розпорядчих заходів, програмно-технічних та інформаційно-телекомунікаційних засобів, що забезпечують формування й ведення інформаційно-довідкових та оперативно-розшукових обліків, а також авторизований доступ до інформаційних ресурсів ІІПС і фіксацію результатів такого доступу. Зазвичай об'єктами обліку, тобто інформаційними ресурсами IIПC, 6 відомості щодо подій, злочинів (правопорушень), осіб, речей, документів, цінностей та іншого майна, які підлягають обліку, та зв'язки між ними. Форми ведення цих обліків можуть бути різноманітними - криміналістичні довідники, колекції, інформаційно-пошукові комп'ютерні системи, картотеки, каталоги продукції фірм виробників [1, с. 91-105].

На жаль, як вказував відомий ученийкриміналіст Р.С. Бєлкін, потенційні можливості використання експертно-криміналістичних обліків для розкриття і розслідування злочинів реалізуються не в повну силу. У результаті чого, саме ця обставина змушує не лише переглянути, а й внести конкретні поправки в наукову і перш за все правову основу окремої теорії про криміналістичну реєстрацію [2, с. 187]. У цьому сенсі відзначається, що криміналістичні обліки не лише обов'язково мають причинно-наслідковий зв'язок з подією злочину, а й реєстраційні (інформаційні) ознаки їх об'єктів виявляються шляхом спеціальних досліджень, що проводяться 3 використанням криміналістичної техніки і спеціальних знань [3, с. 372].

Так, у кримінальних провадженнях щодо корупційних злочинів слідчим можуть бути використані автоматизовані інформаційно-пошукові (інформаційно-довідкові) системи, що дозволяють отримувати важливу для слідства інформацію про можливі напрями розслідування:

- підсистема «Корупиія»: містить інформацію щодо всіх зареєстрованих адміні- 
стративних і кримінальних корупційних правопорушень, результатів їх вирішення по суті у межах відповідної форми судочинства (склад корупційного правопорушення, стаття, відповідно до якої особу притягнуто до відповідальності, дата набрання законної сили судовим рішенням тощо) та службових осіб, які вчинили зазначені корупційні правопорушення (ідентифікаційні дані, сфера діяльності, посада, службовий ранг на час вчинення правопорушення і т.д.);

- автоматизована інбормачійно-пошукова система «Підробка»: обліку підлягають грошові знаки, цінні папери і бланки документів, які містять ознаки підробки, зокрема відомості про спосіб такого підроблення, ознаки первинного змісту документа, використовувану технологію та спосіб виготовлення документа або банкноти, способи імітації голографічних захисних елементів, дані щодо збувальників і виготовлювачів підроблених документів (паперових грошових знаків) тощо;

- підсистема "Документ»: за результатами перевірки слідчий має можливість встановити, що вилучений у певної службової особи документ перебуває на обліку у якості викраденого або втраченого; в електронній картці підсистеми зазначаються відомості щодо часу, місця та підстав взяття на облік такого документа, дані щодо установи або особи, у яких було викрадено або вилучено документ, відомості щодо результатів проведеного експертного дослідження тощо;

- інші види обліків з урахуванням виду корупційного злочину та конкретної слідчої ситуації (картотека слідів рук та дактилоскопічних карт, обліки щодо зареєстрованих адміністративних правопорушень, транспортних засобів, що розшукуються, викрадених предметів, що мають історичну, культурну або художню цінність, заборонених чи обмежених в обороті речей, що були вилучені у службових осіб тощо).

Зазначені інформаційно-пошукові (інформаційно-довідкові) системи сприяють ідентифікації та розшуку осіб, причетних до вчинення корупційного злочину, встановленню єдиного джерела походження документів, бланки яких віддруковані з ви- користанням одного друкарського устаткування, конкретних друкованих форм або кліше, виявленню осіб, які займаються їх виготовленням тощо. За допомогою таких підсистем слідчий отримує узагальнені дані про спосіб, типові сліди та механізм вчинених корупційних дій, особистість і характерні риси винних осіб, що, у свою чергу, дозволяє правильно кваліфікувати подію, висунути щодо неї обгрунтовані версії, а також додатково оцінити достатність уже зібраних доказів для прийняття конкретного процесуального рішення.

Aле незважаючи на безсумнівно доказове значення одержаних за допомогою експертно-криміналістичних обліків (пошуково-довідкових систем) результатів перевірок, на сьогодні залишаються відсутніми правові підстави використання цієї облікової інформації як самостійних джерел доказів. 3 цього приводу окремі дослідники справедливо наголошують, що при сформованому підході, перевіркам за обліками відводиться лише другорядна незначна роль після криміналістичної експертизи. Це значною мірою знижує кількість звернень до криміналістичної облікової інформації, тим самим перешкоджаючи своєчасному розслідуванню і розкриттю злочинів. Ігнорування слідчими та оперативними підрозділами потенційних можливостей використання криміналістичних обліків веде до утворення цілого ряду проблем, у тому числі і до відсутності порівняльного матеріалу, використовуваного для поповнення баз даних [4, с. 199].

Вважаємо, що така ситуація є нетерпимою і вимагає негайного виправлення шляхом доповнення чинного КПК України відповідними положеннями, що стосуються організації функціонування експертно-криміналістичних обліків, а також визнання результатів перевірок за наявною обліковою інформацією, введеною в систему криміналістичної реєстрації після відповідного експертного дослідження, самостійним джерелом доказів. Правове врегулювання зазначеного питання, на нашу думку, сприятиме підвищенню функціональної ролі криміналістичної реєстрації, оновленню сучасних та створенню нових 


\section{Кримінальне право, кримінальний процес та криміналістика}

видів експертно-криміналістичних обліків, що, безперечно, позитивним чином вплине і на підвищення ефективності їх використання в діяльності правоохоронних органів у цілому.

Одним 3 перспективних напрямів підвищення ефективності організації досудового розслідування корупційних 3лочинів є впровадження новітніх технологій штучного інтелекту. Під останнім традиційно розуміють комп'ютерні програми, програмні комплекси, які здатні не просто діяти по заздалегідь заданому алгоритму, а й реалізовувати такі іманентні людині творчі функції, як прогнозування, оцінка ризиків, робота 3 неповними даними і т.д. [5, с. 43]. Р.С. Бєлкін, досліджуючи злободенні питання вітчизняної криміналістики, ще майже двадцять років тому цілком доречно відзначав, що рядовий слідчий без великого професійного досвіду в умовах дефіциту часу і екстремальної ситуації не в змозі відтворити в пам'яті десятки сторінок «книжкової методики» в якості оперативного керівництва до дій. Для успішного вирішення цього питання вчений пропонував розробку з опорою на сучасний науковий досвід лаконічних, чітких і ясних алгоритмів дій слідчого i їх варіантів для вибору в залежності від слідчих ситуацій [6, с. 127-128]. 3 розвитком сучасних інформаційних технологій це питання є особливо актуальним.

Так, у криміналістичних джерелах визначаються можливості штучних нейронних мереж, які можуть бути реалізовані в наступних окремих і загальних напрямках: 1) оцінка вихідної інформації у кримінальному провадженні з метою висунення простих і комплексних слідчих версій, визначення напрямків їх перевірки; 2) моделювання події злочину і його слідової картини на основі неповних даних і попереднього «досвіду», що охоплює великий масив кримінальних проваджень; 3) виявлення ознак серійності в умовах інформаційної недостатності і пропозиція варіантів дій слідчого по перевірці перспективних слідчих версій; 4) збільшення ефективності почеркознавчих i габітоскопічних досліджень: до теперішнього часу найбільш перспек- тивним напрямком розвитку штучних нейронних мереж вважається розпізнавання образів, що може дозволити, наприклад, автоматизацію виявлення ознак підробки документів; 5) пошук недоступних криміналістичному програмному забезпеченню комп'ютерних файлів, прихованих, наприклад, за допомогою стеганографії або альтернативних потоків даних (ADS), встановлення первинного джерела інформації в мережі Інтернет; 6) прогнозування скоєння злочину в майбутньому, на основі аналізу ознак вчинених злочинів з точки зору їх локалізації, соціальних характеристик певних категорій осіб, засобів масової інформації тощо [5, с. 46; 7; 8; 9].

Наразі у світовій практиці розкриття i розслідування злочинів активно використовуються різноманітні комп'ютерні криміналістичні програми, спрямовані на вироблення програми дій слідчого 3 урахуванням конкретних слідчих ситуацій. Так, професором В.Ю. Толстолуцьким запропоновано комп'ютерну криміналістичну програму «Форвер», яка формує версії і містить технологію розкриття злочинів [10]. Крім того, у діяльність правоохоронних органів впроваджено автоматизовані інформаційно-пошукові системи, що дозволяють отримувати інформацію про можливі напрямки розслідування: система «Блок», що забезпечує інформаційний криміналістичний супровід розслідування економічних злочинів; система «Спрут», яка допомагає встановити контактні зв'язки злочинців; система «Сейф», в якій систематизується інформація про розкрадання грошових коштів зі сховищ; географічна інформаційна система «Дзеркало», що оперує просторовими (фактографічними і статистичними) даними, та ін. $[5$, c. 44].

Тож, як бачимо, забезпечення кримінального судочинства новітніми системами штучного інтелекту має безліч переваг, які виявляються насамперед у можливості обробки та аналізу величезних масивів даних у максимально стислі строки, що набуває суттєвого значення в умовах надмірної завантаженості слідчих, які 3 об'єктивних причин не в змозі приділити достатньої уваги здійсненню грунтовної аналітичної 
роботи, на виконання якої може знадобитися більше часу, ніж це було б можливо у межах розслідування кримінального провадження. Разом із цим, використання штучних нейронних мереж може обумовлюватися й необхідністю одержання додаткової технічної допомоги, зокрема під час вивчення значної кількості документів, пошуку прихованих комп'ютерних файлів, опрацювання великих обсягів інтернет i мультимедіа-контенту, розпізнавання осіб 3 фотографій або камер відеоспостереження тощо, на що може піти до кількох місяців безперервної роботи навіть для цілого складу слідчо-оперативної групи. Таким чином, слідчий, звілняючись від трудомісткої та рутинної роботи, отримує вже готовий результат - більш точні і релевантні висновки в найкоротші терміни, що, у свою чергу, дозволяє значно розширити обсяги використання криміналістично значимої інформації, реалізувати функцію логічного контролю прийняття оптимальних тактичних рішень та, як наслідок, забезпечити своєчасність провадження досудового розслідування.

3 огляду на зазначене вбачається можливість створення і впровадження у правоохоронну діяльність автоматизованої консультаційно-аналітичної системи під умовною назвою «Протидія корупційній злочинності», що може слугувати додатковим методичним ресурсом, який забезпечить інформаційний криміналістичний супровід розслідування корупційних злочинів та дозволить компенсувати відсутність практичного досвіду у співробітників правоохоронних органів, які здійснюють кримінальне провадження щодо цієї категорії злочинів. До цієї системи можуть бути включені:

1) консультаиійний модуль, що забезпечить збір, обробку та зберігання узагальненої інформаційно-довідкової інформації про корупційні злочини, до джерел даних якої належать: криміналістична характеристика зазначених злочинів та зміст їі окремих структурних елементів; матеріали кримінальних проваджень даної категорії в оцифрованому вигляді; результати ревізій, документальних перевірок, інвентаризацій та інших контрольно-перевірочних заходів, що проводилися щодо визначеного господарюючого суб'єкта відповідними контрольно-наглядовими державними органами; банки даних вилучених документів, які мають ознаки матеріального або інтелектуального підроблення тощо;

2) аналітичний модуль, спрямований на реалізацію наступних завдань і функцій: виявлення прихованих зв'язків між окремими фактами, подіями і особами, причетними до вчинення корупційного злочину; оцінка наявного у розпорядженні слідчого вихідного матеріалу кримінального провадження, організація та планування слідчо-оперативних заходів, прогнозування подальшого напряму розслідування; повний перебір та висування слідчих версій з урахуванням одержаної інформації щодо обставин розслідуваної події та ймовірного портрета злочинця, оцінка достатності зібраних доказів, виявлення тактичних та процесуальних помилок; прогнозування майбутніх корупційних злочинних проявів у певній сфері діяльності службових та посадових осіб на основі аналізу характерних ознак вчиненого корупційного злочину тощо.

\section{Висновки}

Звичайно, ми не можемо говорити про повну заміну розумової діяльності слідчого аналогічними можливостями штучних нейронних мереж, проте їх інтеграція, безперечно, є одним 3 найбільш перспективних напрямів інформаційного забезпечення розслідування злочинів, у тому числі і корупційної спрямованості, який потребує подальшої прискіпливої уваги науковців та відповідної практичної апробації висунутих теоретичних положень, а також удосконалення чинного кримінального процесуального законодавтва в контексті закріплення можливості використання сучасних технологій штучного інтелекту у сфері реалізації правоохоронної діяльності.

\section{Література}

1. Криміналістика: підручник: у 2 т. Т. $1 /$ А.Ф. Волобуєв, М.В. Даньшин, А.В. Іщенко та ін.; за заг. ред. А.Ф. Волобуєва, Р.А. Сте- 


\section{Кримінальне право, кримінальний процес та криміналістика}

панюка, В.О. Малярової. Харків: Харків. нац. ун-т внутр. справ, 2018. 384 с.

2. Белкин Р.С. Криминалистическая энциклопедия. Москва: Мегатрон XXI, 2000. 334 c.

3. Аверьянова Т.В., Белкин Р.С., Корухов Ю.Г., Россинская Е.Р. Криминалистика / Под ред. Р.С. Белкина. Москва: НОРМАИНФРА-М, 1999. 990 с.

4. Кочерга А.А. Объективный взгляд на потенциальное доказательственное значение криминалистических учетов с позиции эффективности их использования. Общество и право. 2011. № 1 (33). С. 195-199.

5. Бахтеев Д.В. Искусственный интеллект в криминалистике: состояние и перспективы использования. Российское право: Образование. Практика. Наука. 2018. № 2. С. 43-49.

6. Белкин Р.С. Криминалистика: проблемы сегодняшнего дня. Злободневные вопросы российской криминалистики. Москва: Инфра-М; Норма, 2001. 240 c.

7. Harris R.M. Using Artificial Neural Networks for Forensic File Type Identification. Master's thesis. West Lafayette: Purdue University, 2007. $66 \mathrm{p}$

8. Norton A. Predictive Policing - The Future of Law Enforcement in the Trinidad and Tobago Police Service // International Journal of Computer Applications. 2013. Vol. 62. № 4. P. 32-36.

9. Яковец Е.Н. Проблемы аналитической работы в оперативно-розыскной деятельности органов внутренних дел. Москва: Издат. дом И.И. Шумиловой, 2005. 219 c.

10. Толстолуцкий В.Ю. Компьютерная

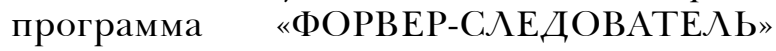
повышает эффективность обучения на криминалистическом полигоне. Вестник Нижегородского университета им. Н.И. Аобачевско2o. 2013. № 3 (2), c. 211-215.
The article identifies the place and role of automated information retrieval systems as a nonprocedural form of using special knowledge in the investigation of corruption crimes. It is noted that in practice their use is associated primarily with the need to obtain indicative information in the proceedings of this category, which greatly expands the practical capabilities of the investigator in understanding the phenomena and processes that are characteristic of corruption, taking into account the specifics of the latter. Attention is drawn to the procedural shortcomings in the lack of legal grounds for using this credentials as independent sources of evidence, which significantly reduces the number of appeals to forensic credentials, thereby hindering the timely investigation and detection of crimes, leading to a number of problems, including and in the absence of comparative material used to replenish databases. The necessity of making amendments to the CPC of Ukraine to eliminate these errors is substantiated. The current state of artificial intelligence technologies, its concepts and main directions of development are considered. It is noted that the provision of criminal justice with the latest artificial intelligence systems has many advantages, which are manifested primarily in the ability to process and analyze huge data sets in the shortest possible time, which becomes essential in terms of overcrowding of investigators who for objective reasons can not pay sufficient attention to the implementation of thorough analytical work, which may take longer than would be possible in the investigation of criminal proceedings. In view of the above, it is proposed to create and implement in law enforcement an automated consulting and analytical system conditionally called "Combating Corruption Crime", which can serve as an additional methodological resource that will provide forensic information support of corruption crimes and compensate for the lack of practical experience who carry out criminal proceedings against this category of crimes.

Key words: crime, corruption, counteraction, criminalistics, forensic accounting, artificial intelligence technologies. 